УДК 81’33:343.301

DOI https://doi.org/10.26661/2414-9594-2021-1-11

\title{
НОВІ НАПРЯМИ РОЗВИТКУ КРИМІНАЛІСТИЧНОЇ ЛІНГВІСТИКИ: ПОПЕРЕДЖЕННЯ ТА ПРОТИДІЯ ТЕРОРИСТИЧНІЙ ДІЯЛЬНОСТІ
}

\author{
Каліщук Д. М. \\ кандидат філологічних наук, \\ доиент кафедри прикладної лінгвістики \\ Волинський національний університет імені Лесі Украӥнки \\ пр. Волі, 13, Луиььк, Украӥна \\ orcid.org/0000-0003-1952-5176 \\ diana_kalishchuk@vnu.edu.ua \\ Бондар Т. Г. \\ кандидат філологічних наук, \\ доиент кафедри прикладної лінгвістики \\ Волинський національний університет імені Лесі Украӥнки \\ пр. Волі, 13, Луиьк, Украӥна \\ orcid.org/0000-0002-9421-264X \\ Bondar.Tetiana@vnu.edu.ua
}

\begin{abstract}
Ключові слова:
криміналістична

лінгвістика, тероризм, терористична діяльність, аналіз оперативних даних, лінгвістичний аналіз, розслідування під прикриттям.
\end{abstract}

У сучасному глобалізованому світі під впливом різноманітних суспільнополітичних, економічних, релігійних та інших факторів прояви тероризму та терористичні атаки стають все частотнішими та жорстокішими. Уряди багатьох країн включили попередження та боротьбу з тероризму до головних пріоритетів своєї діяльності. Тероризм розглядають як одну з багатьох форм відносин між індивідами, групами, певними суспільствами або режимами правління та їх громадянами, яка має дуже специфічний характер. В останні десятиліття значна увага приділяється аналізу причин виникнення таких відносин, що могло б допомогти виявляти потенційну терористичну діяльність та запобігати їй. Серед головних напрямів дослідження тероризму як явища можна виокремити аналіз проблеми визначення тероризму, способів та засобів протидії терористичній діяльності, використання дипломатичних методів та міжнародної співпраці, міжнародного фінансування тероризму тощо. Проте все ще недостатня увага приділяється залученню лінгвістів-криміналістів до аналізу оперативних даних, які можуть слугувати доказами в суді.

Статтю присвячено проблемі застосування методів лінгвістичного аналізу до оброблення даних, що використовуються у розслідуваннях чи судових процесах, пов'язаних зпопередженням, протидією чи боротьбою з тероризмом. Головними критеріями успішних розслідувань вважають наявність достатніх підстав для підозри щодо потенційної терористичної діяльності, розроблення плану для затримання підозрюваних за умови переконливих доказів, вміння виокремити на записах мовний матеріал, що переконливо доводить вину підозрюваних, а не відображає штучно створену самим агентом ситуацію, ретельне оброблення, зокрема лінгвістичне, отриманих оперативних даних. Головними комунікативними стратегіями, які використовують агенти під прикриттям, вважаються надання можливості підозрюваним говорити вільно і в такий спосіб генерувати свою вину власноруч; надання натяків і недомовок, якими може скористатись підозрюваний, щоб розкрити власну вину; чітке та недвозначне розкриття незаконності справи, яка планується. Лінгвістичний аналіззаписів, отриманих у результаті таємноїоперації, дає можливість виявити імпліцитні та експліцитні смисли, які вкладають у значення певних мовних одиниць підозрювані та агент, виокремити стратегії, які вони використовують, визначити ступінь залучення агентів у створення та постановку ситуації, отже, довести чи спростувати вину підозрюваних. 


\title{
NEW DIRECTIONS OF FORENSIC LINGUISTICS DEVELOPMENT: TERRORIST ACTIVITY PREVENTION AND COUNTERACTION
}

\author{
Kalishchuk D. M. \\ Ph.D. in Germanic Languages, \\ Associate Professor at the Department of Applied Linguistics \\ Lesya Ukrainka Volyn National University \\ Volia avenue, 13, Lutsk, Ukraine \\ orcid.org/0000-0003-1952-5176 \\ diana_kalishchuk@vnu.edu.ua
}

Bondar T. H.

Ph.D. in Linguistics, Associate Professor at the Department of Applied Linguistics

Lesya Ukrainka Volyn National University

Volia avenue, 13, Lutsk, Ukraine

orcid.org/0000-0002-9421-264X

Bondar.Tetiana@vnu.edu.ua

Key words: forensic linguistics, terrorism, terrorist activity, intelligence analysis, linguistic analysis, undercover investigation.
In the modern globalized world under the influence of various social political, economic, religious and other factors cases of terrorism and terrorist attacks are becoming more and more frequent and violent. Governments of many countries have included terrorism prevention and counteraction to their main priorities. Terrorism is treated as one of the many forms of relations between individuals, groups, certain societies or regimes and citizens, this form of relations is of a rather specific type. In recent decades considerable attention is paid to the analysis of the reasons of such activity which may help detect and counteract potential terrorist activity. The main directions of investigation of terrorism are the analysis of the issues of this phenomenon definition, means and ways of terrorist activity counteraction, usage of diplomatic methods and international cooperation, international financing of terrorism, etc. Still not enough attention is paid to involvement of forensic linguists to the intelligence analysis of data which may be used as evidence in court.

The article is devoted to the issues of applying methods of linguistic analysis to process data, used in investigations and trials concerned with prevention. Counteraction and fight against terrorism. The main criteria of successful investigations are reasonable grounds to suspect potential terrorist activity, elaboration of the plan to arrest the suspects in case the evidence is persuasive enough, the skills to properly analyze the recordings and single out linguistic data that prove the guilt of suspects but not reflect the situation artificially created by the agent, careful data processing including linguistic analysis. The main communicative strategies used by undercover agents are as follows: to allow the suspects to talk freely thus generating their guilt on their own; drop hints and reservations which may be used by suspects to reveal their guilt; clearly and unambiguously explain that the action planned is illegal. Linguistic analysis of the obtained data allows the researcher to reveal explicit and implicit meanings of certain linguistic units used by suspects and the agent, single out the strategies applied by them, define the level of the agent's involvement in creation and staging of the situation and, therefore, to prove or deny the guilt of suspects. 
Вступ. Сучасний світ стає дедалі більш радикалізованим, маючи в основі цієї тенденції кризові явища суспільно-політичної, економічної, політичної сфер, які посилюються у періоди епідемій чи пандемій, а також значно піддаються зовнішньоекономічному, геополітичному впливу, як і впливу міжетнічних чи міжрелігійних контекстів. Усі зазначені фактори сприяють тому, що прояви тероризму у світі стають дедалі частотнішими та жорстокішими. Стрімкий розвиток інформаційних технологій переводить запобігання терористичній діяльності та боротьбу з нею на новий рівень та у новий, цифровий, вимір.

Розроблення теоретико-методологічних засад та вивчення окремих аспектів протидії та боротьби 3 тероризмом набувають усе більшої актуальності останніми роками. Міжнародний та глобальний тероризм аналізують такі вітчизняні вчені, як М.Я. Гуцман, I.В. Шкурат, М.М. Кучерук [3; 11; 7]. В.Ф. Антипенко, А.В. Антипенко працюють у сфері кримінології як науки, зокрема розробляють аспекти виокремлення міжнародної кримінології тероризму як окремої галузі [1]. Ю.Б. Данильченко аналізує тероризм як феномен, проблеми дефініції та способи протидії [4]. Методологічні засади боротьби з тероризмом в Україні та міжнародний тероризм аналізуються у працях В.В. Крутова [10]. В.А. Ліпкан досліджує тероризм та інші злочини терористичного характеру [8]. У монографії I.M. Рижова аналізуються базові концепти антитерористичної безпеки [9]. Зарубіжні вчені також активно досліджують проблематику терористичної діяльності, зосереджуючись передусім на політичному та глобальному тероризмі. Заслуговують на увагу такі праці, як «Машина часу // Тероризм» Л. Діспо [6], «Тероризм проти ліберальної демократії» П. Вілкінсона [21], «Політичний тероризм: дослідження концепцій, теорій та літератури» А. Шмідта, «Політичний тероризм: теорія, тактики, протидія» Г. Вордло [20], «Стратегія антитерору» Г. Денікера [5], «Терористичний виклик» Р. Соле [19], «Походження міжнародного тероризму» Р. Фрідланда [12], "Introducing the Global Terrorism Database" G. LaFree, L, Dugan [15], "The Psychology of Terrorism" J. Horgan [14].

Незважаючи на велику кількість досліджень, підхід до аналізу тероризму як явища залишається традиційним, більшість праць присвячено кримінологічному аспекту тероризму як злочину, немає узгодженості щодо термінології, не вироблено понятійно-дефініційних критеріїв. Проте події останнього часу в Україні і світі переконливо доводять, що нові виклики вимагають розроблення та впровадження нових методів, використання різноманітних ресурсів та навиків, в тому числі професійних лінгвістичних знань, що зумовлює актуальність нашого дослідження, метою якого $є$ доведення необхідності залучення не лише силових структур чи спеціалістів служби безпеки, але й лінгвістів-криміналістів до аналізу даних, розслідувань чи судових процесів, які пов'язані з попередженням, протидією чи боротьбою з терористичною діяльністю.

Методи та методики дослідження. У дослідженні були використані такі методи аналізу, як загальнонауковий гіпотетико-дедуктивний метод, метод спостереження надлінгвальним матеріалом, описовий метод, а також такі теоретичні методи дослідження, як аналіз, синтез, порівняння, узагальнення, систематизація наукових джерел, для характеристики інструментарію лінгвістичного аналізу оперативних та інших даних.

Результати та дискусії. Проблеми боротьби 3 тероризмом входять до основних пріоритетів спецслужб різних країн. ФБР, наприклад, включає захист держави від терористичних нападів у трійку головних завдань поруч із протидією шпигунству та злочинам, що пов'язані з високими технологіями та кіберзлочинністю. Тероризм слід розглядати як передусім одну з багатьох форм відносин, дуже специфічну, між індивідами, групами, певними суспільствами або режимами правління та їх громадянами. Отже, ідеться саме про форму відносин між людьми, хоч і вкрай радикальну [2, с. 3]. Причини виникнення таких відносин потребують ретельного вивчення, що могло б допомогти запобігти виникненню таких відносин і терористичним атакам.

В останні десятиліття увага до тероризму як явища посилюється, ведуться дискусії щодо проблеми визначення тероризму, досліджуються засоби та способи протидії терористичній діяльності, широко обговорюються використання дипломатії та міжнародної співпраці, міжнародне фінансування терористичних угруповань та організацій тощо. Проте, на жаль, недостатньо уваги приділяється власне лінгвістичним аспектам. У Сполучених Штатах нові дослідження проводяться в межах криміналістичної лінгвістики. Представники цього напряму лінгвістики переконливо доводять необхідність залучення знань та навичок лінгвістів-криміналістів до роботи 3 даними, отриманими в результаті розслідувань чи таємних операцій, розроблених спецслужбами для боротьби з тероризмом.

Як стверджує спеціаліст у сфері криміналістичної лінгвістики 3 університету Джорджтауна Роджер Шай, що першим почав застосовувати дискурс-аналіз для аналізу записів розмов чи писемної комунікації, які стосувалися злочинної чи потенційно злочинної діяльності, успішні розслідування терористичної діяльності повинні відповідати певним критеріям. Перш за все повинні бути достатні підстави для підозри, що певна 
терористична діяльність відбувається чи може відбуватись. Наступним критерієм є розроблення плану для затримання підозрюваного чи підозрюваних за умови, що є переконливі докази вірогідності того, що терористична діяльність може відбутись [17, с. 558]. Оскільки операції, пов'язані 3 викриттям потенційних терористів, часто передбачають роботу під прикриттям, під час якої проводиться запис численних розмов, аналіз таких записів вимагає особливої уваги, оскільки часто потенційні підозрювані розмовляють 3 тими, хто не має жодних злочинних намірів, тому потрібно сортувати репліки, тобто чітко відокремлювати слова підозрюваних від слів тих, хто не має жодного відношення до терористичної діяльності.

Третім критерієм, на думку Роджера Шая, є вимога до агента, що працював під прикриттям i проводив запис розмов, виявити на записах неспростовні докази того, що потенційні підозрювані $є$ винними у скоєнні злочинних дій чи насправді мають злочинні наміри [17, с. 559]. Це не просте завдання, оскільки отримання таких доказів значною мірою залежить від умінь агента уникнути штучного створення злочину, виокремлення мовного матеріалу, який буде використовуватись в суді як свідчення обвинувачення і передусім явно чи неявно не змушувати підозрюваних говорити те, що агент хоче почути. Останньою вимогою є оброблення інформації, яку зібрав агент під прикриттям. Дані, які можуть потенційно бути використані в суді як докази сторони обвинувачення, повинні бути ретельно оцінені прокурором і взяті до уваги тільки тоді, коли вони відповідають усім законним вимогам, a їх доказовий потенціал не викликає жодних сумнівів [17, с. 559].

Якщо усі вищенаведені вимоги виконуються, розслідування можна вважати успішним, а результат - справедливим. Проте відомі випадки, коли 3 певних причин одна чи більше вимог не виконувались. У намаганні досягти мети - захист населення від терористичної діяльності - на певному етапі відбувалась неправильна інтерпретація реально зібраних даних, робились висновки без достатніх підстав, приймались поспішні та необгрунтовані рішення, результатом чого могли бути скалічені життя невинних людей, засуджених несправедливо.

Незважаючи на зростаючу роль лінгвістів-експертів у розслідуваннях, пов'язаних із терористичною діяльністю, все ще недостатня увага приділяється власне лінгвістичній інтерпретації даних, лінгвістичному аналізу доказів, який нічим не відрізняється від аналізу даних у будь-яких інших випадках, де головними доказами слугують записи розмов підозрюваних. Існує низка проблем, пов'язаних із роботою детективів, агентів під прикриттям, які залученні у розслідування та попередження потенційних терористичних атак.

Перша 3 них - це виявлення справжніх підозрюваних, осіб, які дійсно можуть планувати потенційні терористичні акти. Існує тенденція, коли таємні агенти звертають увагу на людей, які недостатньо освічені, легковірні, заглиблені у власні переживання. Дуже часто це вихідці з інших країн, які недостатньо добре володіють мовою, тому не завжди розуміють певні мовні нюанси, через що їх легко можна ввести в оману. Власне, саме на цьому етапі потрібні професійні лінгвістичні знання, щоб розрізнити, що саме хотів чи не хотів сказати мовець, запис розмови якого аналізується. В останні десятиліття є багато випадків у Сполучених Штатах Америки, коли потенційна терористична діяльність була створена та заохочена власне агентами під прикриттям, підозрювані, серед яких переважно були вихідці із Середнього Сходу, частину з яких складали громадяни Америки, могли бути виправдані судом присяжних через недостатню переконливість доказів.

Часто під час розслідування потенційної терористичної діяльності агенти під прикриттям таємно записують сотні годин розмов. Коли доказами слугують записи розмов, учасники судового процесу часто виявляють тенденцію визнати підозрюваних винними на підставі лише того факту, що їх голос є на плівці і вони просто були присутні під час здійснення запису. У розгляді таких справ здійснюють так званий аналіз оперативних даних (intelligence analysis). Першочерговою метою такого аналізу є отримання чітких записів того, що було сказано і ким, тоді все зводять разом із контекстом як доказ, проводять виокремлення та розмежування таких мовленнєвих актів, як згода та заперечення, а також виявлення моментів, коли особи, яких записують, або не чули, або не реагували на те, що до них говорять [13, с. 30-34].

Важливість залучення лінгвіста-експерта до експертизи записів розмов, які слугують доказами в суді, переконливо доводить професор Роджер Шай. Під час аналізу плівок залучаються лінгвістичні знання з фонетики, морфології та синтаксису для корегування записів; знання зі сфер дискурс-аналізу, семантики та прагматики для виявлення i відслідковування головних топіків, тем, схем та планів мовців; знання теорії мовленнєвих актів для виявлення та чіткого й точного розмежування різних важливих для справи мовців, які просять, обіцяють, погоджуються, заперечують тощо; організаційні навички, щоб звести все це до вигляду, який буде зрозумілим для присяжних чи інших осіб [17]. Проводячи такий аналіз, лінгвісти висувають різні гіпотези, а не лише одну - гіпотезу вини.

Професор Р. Шай дуже детально аналізує судовий процес, до якого він був залучений 
як консультант, що відбувся в Толедо, штат Огайо, а саме «Сполучені Штати проти Могамада Амаві, Марвана Ель-Хінді і Васіма Мазлоума», де названі особибулизвинуваченіутерористичнійдіяльності. Усі троє були мусульманами, жили в Толедо, проте не були знайомі між собою до того часу, як їх ніби випадково познайомив агент під прикриттям. Роджер Шай провів лінгвістичний аналіз записів, зроблених агентом, які слугували доказами в суді і на підставі яких підозрювані були звинувачені у підготовці терористичного акту. В результаті здійсненого аналізу він довів, що дійсні наміри Марвана Ель-Хінді були далекими від тих, у яких він був звинувачений. Також було доведено, що агент сам створив докази ймовірних протизаконних намірів Ель-Хінді і скористався його нездатністю уважно слухати та інтерпретувати двозначність, приховані сенси та натяки агента. Врешті професор Р. Шай довів, що коли агенту не вдалося заохотити Ель-Хінді до створення тренувальної терористичної групи, він відмовився від цього сценарію і натомість створив новий. За новим сценарієм, агент попросив Ель-Хінді завантажити певні відеозаписи та інтернет-трансляції із Середнього Сходу та надіслати агенту на електронну адресу. На підставі цих дій усі троє підозрюваних були звинувачені у співучасті та підбурюванні до терористичної діяльності [17].

У випадках, що стосуються терористичної діяльності, завданнями сторони обвинувачення чи слідчих органів $є$ виявлення мотивації підозрюваних, розроблення сценарію, за яким можливо було б вести записи злочинної діяльності чи намірів, а також використання таких комунікативних стратегій, які б заохотили підозрюваних видати свої протизаконні наміри, тобто створюється вірогідний варіант розвитку подій, за якого потенційний терористичний акт міг би відбутись. Агент, що працював під прикриттям, вів спостереження за людьми в мечетях, провокував їх на висловлення невдоволення діями американського уряду тощо. Він звернув увагу на Амаві, який часто говорив про те, що ненавидить війну в Іраку, значна частина 300-годинних записів розмов $є$ записами саме Амаві. Наступним об'єктом став Ель-Хінді, котрий вихвалявся своїм бізнес-потенціалом. Оскільки будь-який терористичний акт потребує фінансування, він видався перспективним кандидатом. Мазлоум був, швидше, випадковим учасником, він присутній на незначній кількості записів.

Агентом було розроблено два можливі варіанти розвитку подій, до яких він планував залучити вибраних об'єктів. Згідно 3 першим сценарієм, потрібно було спонукати Ель-Хінді до створення групи, ймовірно, терористичної, проте прямо про це агент жодного разу не говорив. Йшлося про тренування людей, мета цього тренування була доволі розмитою. Слово “training”, як виявилось у процесі аналізу, було одним із ключових неоднозначних сумнівних слів у ході судового процесу. Оскільки обоє фігурантів, Ель-Хінді та Мазлоум, мали надлишкову вагу та були в не дуже хорошому фізичному стані, для них тренування, які обіцяв забезпечити колишній солдат армії США, а тепер агент під прикриттям, були необхідні. Агент неодноразово натякав на залучення інших людей до цих тренувань. Ель-Хінді навіть називав прізвища знайомих, які могли би бути потенційними учасниками, проте жоден із них так і не був запрошений на тренування, тому варіант зі створенням групи не вдався.

Після приблизно року невдалих спроб створити так звану терористичну групу був розроблений новий план дій, який у суді був названий як «електронний джихад». Як усі іммігранти, фігуранти справи цікавились новинами 3 історичної батьківщини, тому доволі часто дивились відповідні програми та інтернет-трансляції. Агент Гріффін представлявся їм як новонавернений у мусульманство, тому цілком природно, що під час зустрічей у підозрюваних вдома вони намагались якомога більше розмовляти про релігію. Усі докази, які фігурували в суді, були зібрані саме під час таких зустрічей, це були аудіо- та відеозаписи розмов, а також матеріали, які підозрювані, зокрема Ель-Хінді, надсилали агенту Гріффіну за його ж проханням на електронну пошту.

Агенти, що працюють під прикриттям, зазвичай застосовують такі комунікативні стратегії в межах трикрокового процесу:

- дати можливість підозрюваним говорити вільно, генеруючи свою вину власноруч; якщо твердження, що підтверджують винуватість, таким чином не створені, тоді потрібно перейти до наступного кроку;

- давати натяки та недомовки, якими підозрюваний може скористатись і розкрити власну винуватість; якщо підозрюваний і на цьому етапі не говорить нічого, що може слугувати виразом вини, потрібно переходити на наступний етап;

- чітко та недвозначно розкрити незаконність справи, яка планується [16, с. 7-9].

Агент Гріффін ніколи не заходив далі кроку 2. Він успішно застосовував стратегію неоднозначності у розмовах із підозрюваними, зокрема з ЕльХінді, намагаючись змусити їх самих озвучити ті значенні, які були закладені ним у певні слова. Ці записи слугували доказами в суді. Сторона обвинувачення доводила, що підозрювані добре розуміли, про що йдеться, хоча навіть носії мови не завжди можуть розпізнати стратегію використання неоднозначності, особливо коли замислені над власними справами та не дуже вслухаються в саму розмову. 
Аналізуючи вживання слова “training”, яке у суді трактувалось як тренування та підготовка терористичної групи, тому що саме таке значення закладав у це слово агент Гріффін, Роджер Шай доводить, що підозрюваний Ель-Хінді жодного разу не використовує це слово в такому значенні. Було проаналізовано 13 розмов з Ель-Хінді, записаних протягом трьох років. Агент Гріффін вживає слово "training" 122 рази, з яких у 111 випадках значення $€$ розмитим, двозначним і не вказує на мету тренування. У решти 11 випадках значення слова було специфіковане самим агентом, не двозначне і стосувалось тренування щодо забезпечення безпеки, тренування сусідських дітей стріляти 3 повітряних рушниць, тренування, як поводитися 3 вогнепальною зброєю для охорони домівки, а також тренування для покращення фізичного стану. Не було зафіксовано жодного випадку прямого недвозначного принаймні натяку на те, що "training" стосується тренувань для скоєння жорсткого джихаду.

В тих самих 13 розмовах Ель-Хінді вживає слово "training" 42 рази, 3 яких лише у 5 випадках воно має нечітке розмите контекстуальне значення. Це видається дивним, що людина 3 невисоким рівнем англійської може висловлюватись чіткіше та зрозуміліше, ніж агент, який є носієм мови. 336 випадків вживання "training" з чітким недвозначним значенням було виокремлено тренування в Корані, тренування для покращення фізичного стану себе та інших, тренування американських мусульман для самозахисту проти тих, хто нападає на них на вулиці та у їхніх домівках, тренування як рекреація, тренування для коней, тренування для отримання грантів та тренування для того, щоб стати сертифікованим перекладачем 3 арабської на англійську і навпаки. Жодного разу Ель-Хінді не говорив про тренування для екстремістського джихаду. Насправді він виступав проти жорстокого джихаду, який чинили інші.

Аналізуючи певні уривки розмов, у яких вживається "training", Роджер Шай доводить, що цілі агента та Ель-Хінді були абсолютно різними. Гріффін дуже часто апелює до слова "security" в контексті режиму секретності, натякаючи на те, що дуже важливо, щоб мусульмани не потрапили під підозру у тренуванні для скоєння джихаду. Для Ель-Хінді "security" означає безпеку, оскільки переважно вживається щодо ситуацій, коли мусульман затримували в аеропортах чи нападали на них на вулицях. Він розповідає про власний досвід, коли його побили і пограбували на вулиці.

Griffin: The biggest thing is security, you know.

El-Hindi: That's what I'm saying.

Griffin: We have to be extra careful because $<\ldots>$ they are after Muslims [17].

На перший погляд, здається, що Ель-Хінді погоджується 3 агентом щодо його визначення слова "security", проте увесь контекст говорить про те, що вони користуються різними схемами. Навіть коли Гріффін наважується висловлюватись трохи конкретніше і відвертіше щодо його намірів залучити фігурантів до тренування користуватися вогнепальною зброєю, Ель-Хінді, очевидно, не розуміє натяків агента.

Griffin: There's definitely stuff to teach kids. You know, it's basic stuff, as far as weapons training. Weapons training is basic.

El-Hindi: I was in good relation with Ji'atan Academy and he trained in [17].

В розмові, уривок $з$ якої наведений вище, йшлося про те, що вони шукали можливість взяти в оренду чи купити будівлю, яка могла б слугувати приміщенням для приватної школи для тренування дітей. У “Ji'atan Academy” проводились заняття 3 карате, тому звернення Ель-Хінді до цього закладу вказує на те, що він інтерпретує використання Гріффіном слова "weapons" як тренування з карате. До цього моменту використання Гріффіном слів "train" та "training" без вказівки на мету цього тренування для Гріффіна означає тренування військового типу, Ель-Хінді ж продовжує трактувати це як тренування для самооборони. Практично всі проаналізовані використання слів "train" та "training" репрезентують очевидні розбіжності в інтерпретації значень цих слів обома мовцями. Таких прикладів, які доводять невинуватість підозрюваних, у проведеному Роджером Шаєм аналізі записаних розмов багато.

Проведений аналіз стосувався не лише імпліцитних значень, закладених у певних словах, та ступеня розуміння їх фігурантами. Роджер Шай аналізував також стратегії, які були використані агентом Гріффіном у намаганні залучити об'єктів до створення терористичної групи. Як уже зазначалось вище, агент ніколи не заходив далі кроку 2 натяки на незаконність діяльності, участь у якій планувалась. Гріффін жодного разу не говорив прямо і відкрито про те, що він замислює незаконну діяльність і хоче залучити до неї фігурантів (крок 3). Професор Р. Шай створив таблицю, в якій навів 47 прикладів таких натяків, які він виокремив у 13 записаних розмовах, та назвав це стратегією фішингу - витягування, вивуджування інформації [18]. Ця стратегія зазнала невдачі, як і намір спонукати Ель-Хінді до створення терористичної групи, оскільки співрозмовники керувались різними схемами.

Griffin: You were saying that you were going to set up an organization over there and all that.

El-Hindi: Orphanages. Not only orphans, but very poor, way below poverty [17].

Гріффін намагається вивідати, 3 якою метою Ель-Хінді планує створити організацію у Сгипті, прагнучи поєднати це 3 власним сценарієм - 
створення терористичної групи. Проте Ель-Хінді, відповідно до власного сценарію, пояснює, що йдеться про притулки для сиріт і бідних.

Наступний уривок взятий із розмови, де Гріффін намагається переконати Ель-Хінді дозволити тренувати двох хлопців, яких той знайшов і поселив у Єгипті з наміром повернути до батьків в Америку.

Griffin: They don't have any training so we gotta get across to them is you just goin' over there to commit suicide. That's not jihad. So we have to reel those guys in.

El-Hindi: I told them, "listen, you have some money. You really wanna benefit the people there?" They said, "yes". I said "let's slaughter soma animals and give to the poor people. And you helping a lot of people". So he gave me money, probably a thousand. And I want to slaughter a lot of, thanks be to God, amen. I wanna give to the poor people. They get the reward. We are going on a mission of change [17].

Очевидно, що Ель-Хінді інтерпретує слово "jihad", що використовує Гріффін, відповідно до власного сценарію - вбивство великої кількості тварин, щоб прогодувати бідних людей.

Таких прикладів, як уже згадувалось, було знайдено 47. Розуміючи, що спроби витягнути якусь інформацію є невдалими, Гріффін втрачає терпіння і стає більш наполегливим.

Griffin; I like to go forward. I wanna do my project.

El-Hindi: This European Medical, if they get ten students, that's fifty thousand dollars brother [17].

Гріффін хоче розпочати проєкт із тренування для потенційних терористів. Ель-Хінді теж хоче втілити свій проєкт - школу, навчання в якій включає фізичні тренування. Отже, вживаючи ті самі слова, мовці діють за різними схемами.

Певні висловлювання самого агента свідчать про те, що він розумів, що усі його спроби спонукати Ель-Хінді до активних дій є невдалими.

Griffin: We all have to play our part. We can't sit and talk any more 'cause that's what too many Muslim brothers are doing right now. They're sitting and talking about it but they're not helping the nation at all [17].

Агент наголошує на тому, що вони нічого не роблять, лише розмовляють. Зрештою, він просить підозрюваних, зокрема Ель-Хінді, надіслати йому на електронну пошту певні записи про події на Середньому Сході, що стало вирішальним доказом для суду присяжних, які визнали підозрюваних винними у підбурюванні до терористичної діяльності. Ель-Хінді засудили до 14 років ув'язнення.

Роджер Шай говорить про те, що 3 огляду на великий страх суспільства перед терористичними атаками після 11 вересня 2001 року, який постійно підігрівається політиками, результат цього судового процесу був передбачуваним. Сторона обви- нувачення не звернулась до лінгвістів-експертів щодо власне лінгвістичного аналізу зібраних даних - записів розмов, які велися протягом трьох років. Вони не були у цьому зацікавлені, оскільки метою полягала в тому, щоби знайти винних i засудити. До лінгвістичного аналізу вдалися адвокати захисту, проте результати не були озвучені в суді, оскільки вони не отримали на це дозволу від судді. Відповідаючи на одне 3 ключових питань стосовно будь-яких розслідувань терористичної діяльності - чи були виявлені правильні підозрювані, чи в розроблення було взято саме тих осіб, Роджер Шай зазначає, що фігуранти справи були абсолютно не тими людьми, які повинні були би бути засудженими. Скориставшись їх наївністю, невпевненістю, недосконалим володінням англійською мовою, агент під прикриттям фактично сфабрикував справу, а лінгвістичний аналіз це переконливо доводить. Проте, на жаль, ці результати не були взяті до уваги.

Висновки. Незважаючи на зростаючу увагу до аналізу тероризму як явища, вивчення та розроблення нових методів та засобів боротьби 3 терористичною діяльністю, проблема залучення лінгвістів-криміналістів до розслідувань та судових процесів, пов'язаних з боротьбою 3 тероризмом, залишається гострою, особливо в Україні. Оброблення оперативних даних, які можуть слугувати доказами, потребує використання методів лінгвістичного аналізу. Зарубіжні дослідники у галузі криміналістичної лінгвістики переконливо доводять, що залучення лінгвістичних знань до аналізу оперативних даних може змінити хід судового процесу, оскільки висуваються множинні гіпотези, які потребують доведення, а не єдина гіпотеза доведення вини підозрюваних, яка зазвичай визначає лінію поведінки учасників судового процесу.

Головними критеріями успішних розслідувань вважають наявність достатніх підстав для підозри щодо потенційної терористичної діяльності; розроблення плану для затримання підозрюваних за умови отримання достатньо переконливих доказів; вміння виокремити на записах мовний матеріал, що переконливо доводить вину підозрюваних, оскільки дуже часто записані розмови відображають штучно створену самим агентом ситуацію; ретельний аналіз, в тому числі лінгвістичний, отриманих оперативних даних. Головними комунікативними стратегіями, якими послуговуються агенти під прикриттям під час проведення таємних операцій, вважають надання можливості підозрюваним говорити вільно і в такий спосіб генерувати свою вину власноруч; надання натяків і недомовок, якими може скористатись підозрюваний, щоб розкрити власну вину; чітке та недвозначне розкриття незаконності справи, яка планується. 
Як доводять численні дослідження, лише лінгвістичний аналіз записів, отриманих у результаті проведення операції під прикриттям, дає можливість виявити імпліцитні та експліцитні смисли, які вкладають у значення певних мовних одиниць підозрювані та агент, виокремити стратегії, які вони використовують, визначити ступінь залучення агентів у створення та постановку ситуації, отже, довести чи спростувати вину підозрюваних. Під час аналізу плівок необхідно залучати лінгвістичні знання з фонетики, морфології та синтаксису для корегування записів; знання зі сфер дискурс-аналізу, семантики та прагматики для виявлення i відслідковування головних топіків, тем, схем та планів мовців; знання теорії мовленнєвих актів для виявлення та чіткого й точного розмежування різних важливих для справи мовців, які просять, обіцяють, погоджуються, заперечують тощо. Усі ці аспекти можуть виявити лише фахівці-лінгвісти, які проводять об’єктивний комплексний аналіз отриманих даних із залученням найширшого контексту, не зосереджуючи увагу лише на певних одиницях із суб'єктивним трактуванням.

Перспективами подальших досліджень вважаємо аналіз судових процесів щодо терористичної діяльності в Україні, виявлення ступеня залучення лінгвістів-криміналістів до роботи з оперативними даними, які можуть слугувати доказами в суді, розроблення рекомендацій щодо проведення лінгвістичного аналізу отриманого мовного матеріалу.

\section{ЛIТЕРАТУРА}

1. Антипенко В.Ф., Антипенко А.В. Методологічні аспекти виокремлення міжнародної кримінології тероризму як напряму науки «кримінологія». Актуальні проблеми міжнародних відносин. 2009. Вип. 87. Ч. ІІ. С. 93-99.

2. Вакулич В.М. Компаративно-політичні виміри та глобалізаційні імперативи міжнародному тероризмові : автореф. дис. ... докт. політ. наук : спец. 23.00.02. Київ, 2008. 23 с.

3. Гуцман М.Я. Роль ООН у боротьбі проти міжнародного тероризму : автореф. дис. ... канд. політ. наук : спец. 23.00.02. Київ, 2008. 20 с.

4. Данильченко Ю.Б. Тероризм: феномен, детермінація, протидія: дис. ... докт. юрид. наук : спец. 12.00.02. Харків, 2018. 443 с.

5. Деникер Г. Стратегія антитерору. Нові шляхи боротьби з тероризмом. Тероризм в сучасному капіталістичному суспільстві. 1982. Вип. 2. С. 76-80.

6. Диспо Л. Машина времени. Терроризм: современные аспекты : сборник научных статей. 1999. С. 31.

7. Кучерук М.М. Протидія тероризму в рамках сучасного міжнародного права : дис. ... канд. юрид. наук : спец. 12.00.02. Київ, 2017. 212 с.

8. Ліпкан В.А., Нікіфорчук Д.Й., Руденко М.М. Боротьба з тероризмом. Політологічний вісник : збірник наукових праць. Київ : Знання України, 2002. С. 47-53.

9. Рижов І.М. Базові концепти антитерористичної безпеки : монографія. Київ : Національна академія СБУ, 2016. 328 с.

10. Коростыленко А.В. и др. Тероризм: определения и сущность : монография / под общ. ред. В.В. Крутова, И.И. Мусиенко, В.А. Глушкова. Киев : Центр учебно-научных и научно-практических изданий НА СБ Украины, 2014. 192 с.

11. Шкурат I.В. Глобальний тероризм: методичні підходи до вивчення. URL: http://www.academy.gov.ua/ ej/ej2/txts/pol-prav/05sivmpv.pdf (дата звернення: 01.03.2021).

12. Friedlande R. The Origins of International Terrorism. Terrorism: Interdisciplinary Perspectives. 2000. P. 34-35.

13. Harris D. Basic Elements of Intelligence. Washington DC : U.S. Law Enforcement Assistance Administration, 1976.

14. Horgan J. The Psychology of Terrorism. London : Routledge, 2005. 184 p.

15. LaFree G., Dugan L. Introducing the Global Terrorism Database. Terrorism and Political Violence. 2017. Vol. 19. Issue 2. P. 181-204. URL: https://doi.org/10.1080/09546550701246817 (дата звернення: 01.03.2021).

16. Shuy R.W. Creating Language Crimes. New York : Oxford University Press, 2005.

17. Shuy R.W. Linguistics and Terrorism Cases. Routledge Handbook of Forensic Linguistics. London : Routledge, 2010. P. 558-575.

18. Shuy R.W. Using language evidence in money laundering trials. American speech. 1993. Vol. 68. No. 1. P. 3-19.

19. Sole R. Le defi terroristc. Paris, 1978. 179 p.

20. Wardlaw G. Political Terrorism: Theory, tactics and counter measures. N.Y. : Press Syndicate of the University of Cambridge, 1986. P. 16. 
21. Wilkinson P. Terrorism versus liberal democracy: The problem of response. The new terrorism: For the Institute for the Study of conflict. Gutteridge W. L.: Mansell, 1986. P. 3-5.

\section{REFERENCES}

1. Antypenko V.F., Antypenko A.V. (2009) Metodolohichni aspekty vyokremlennia mizhnarodnoii kryminologii terorysmu iak napriamu nauky kryminolohiia [Methodological aspects of defining international criminology as a branch of criminology as science]. Actual Problems of International Relations, issue 87, part II, pp. 93-99.

2. Vakulych V.M. (2008) Komparatyvno-politychni vymiry ta hlobalizatsiyni imperatyvy mizhnarodnomu teroryzmovi [Comparative political dimensions and globalization imperatives of international terrorism] (Doctor Thesis), Kyiv.

3. Hutsman M.Ya. (2008) Rol' OON u borot'bi proty mizhnarodnoho teroryzmu [The Role of UN in the fight against international terrorism] (PhD Thesis), Kyiv.

4. Danylchenko Yu.B. Terroryzm: fenomen, determinatsiia, protydiia [Terrorism: the phenomenon, determination, counteraction] (Doctor Thesis), Kharkiv.

5. Denyker H. (1982) Stratehiia antyteroru. Novi shliakhy borot'by z teroryzmom [Antiterror strategy. New ways of fighting terrorism]. Terrorism in Modern Capitalism Society, issue 2, pp. 76-80.

6. Dispo L. (1999) Mashyna vremeni [Time Machine]. Terrorism: Modern Aspects, pp. 31.

7. Kucheruk M.M. (2017) Protydiia teroryzmu v ramkakh suchasnoho mizhnarodnoho prava [Terrorism Counteraction in Terms with Modern International Law] (PhD Thesis), Kyiv.

8. Lipkan V.A., Nikiforchuk D.Y., Rudenko M.M. (2002) Borot'ba z teroryzmom [Fighting Terrorism]. Politological Bulletin, Kyiv: Znannia Ukrainy, pp. 47-53.

9. Ryzhov I. M. (2016) Bazovi kontsepty antyterorystychnoii bezpeky [Basic Concepts of Antiterrorism Safety]. Kyiv: National Academy of SSU. (in Ukrainian)

10. Krutov V.V. ed. (2014) Terrorizm: opredeleniia i sushchost' [Terrorism: definitions and essence]. Kyiv.

11. Shkurat I.V. Hlobalnyi teroryzm: metodychni pidkhody do vyvchennia [Global terrorism: methodological approaches to research] Retrieved from: http://www.academy.gov.ua/ej/ej2/txts/pol-prav/05sivmpv.pdf (accessed: 01.03.2021).

12. Friedlande R. (2000) The Origins of International Terrorism. Terrorism: Interdisciplinary Perspectives, pp. 34-35.

13. Harris D. (1976) Basic Elements of Intelligence. Washington DC: U.S. Law Enforcement Assistance Administration.

14. Horgan J. (2005) The Psychology of Terrorism. London: Routledge.

15. LaFree G., Dugan L. (2017) Introducing the Global Terrorism Database. Terrorism and Political Violence, volume 19, issue 2. P. 181-204. Retrieved from: https://doi.org/10.1080/09546550701246817 (accessed: 01.03.2021).

16. Shuy R.W. (2005) Creating Language Crimes. New York : Oxford University Press.

17. Shuy R. W. (2010) Linguistics and Terrorism Cases. Routledge Handbook of Forensic Linguistics. London: Routledge, pp. 558-575.

18. Shuy R.W. (1993) Using language evidence in money laundering trials. American speech, vol. 68, no. 1, pp. 3-19.

19. Sole R. (1978) Le defi terroristc. 179 p.

20. Wardlaw G. (1986) Political Terrorism: Theory, tactics and counter measures. N.Y.: Press Syndicate of the University of Cambridge, pp. 16.

21. Wilkinson P. (1986) Terrorism versus liberal democracy: The problem of response. The new terrorism: For the Institute for the Study of conflict. Gutteridge W. L.: Mansell, pp. 3-5. 